\title{
Successful Intensive Insulin Treatment of Type 1 Diabetic Dogs Leads to Restoration of Peripheral Leukocyte Insulin Signaling Gene Expression and Enzyme Activities
}

\author{
Akihiro MORI ${ }^{1) *}$, Peter LEE $^{2)}$, Toshinori SAKO ${ }^{1)}$, Hisashi MIZUTANI ${ }^{2)}$ and Toshiro ARAI ${ }^{2)}$ \\ ${ }^{1)}$ School of Veterinary Nursing \& Technology and ${ }^{2}$ School of Veterinary Medicine, Faculty of Veterinary Science, Nippon Veterinary and \\ Life Science University, 1-7-1 Kyonancho, Musashino, Tokyo 180-8602, Japan
}

(Received 19 August 2008/Accepted 10 March 2009) ABSTRACT. The purpose of this study was to investigate whether intensive insulin treatment of dogs suffering from type 1 diabetes mellitus,
resulting in tight glycemic control, could be reflected by changes in peripheral leukocyte metabolism. Specifically, plasma metabolites
and enzyme activities were assessed. In addition, quantitative RT-PCR was used to determine changes in insulin signaling gene (insulin
receptor substrate (IRS)-1, IRS-2 and phosphatidylinositol 3-kinase (PI3-K) P85 $\mathrm{m}$ ) mRA levels in peripheral leukocytes. Lastly, leu-
kocyte enzymes involved in cellular energy metabolism were examined for changes in glucose utilization. Our results indicated that
intensive insulin treatment was successful in type $1 \mathrm{DM}$ dogs, leading to tight glycemic control. The mean glucose concentration and
glycated albumin percentage significantly decreased to $156 \mathrm{mg} / \mathrm{d} l$ and $15.6 \%$, respectively, following treatment. In peripheral leukocytes,
the IRS-2 and PI3-K p $85 \alpha \mathrm{mRNA}$ levels significantly increased, and a significant increase in pyruvate kinase and pyruvate carboxylase
activity, two enzymes involved in cellular energy metabolism, was also observed post treatment. Therefore, the observed changes in
insulin signaling pathway activity and cellular energy metabolism enzyme activity in peripheral leukocytes are considered to be charac-
teristics of amelioration of glucose metabolism by insulin action. As such, peripheral leukocytes are sufficiently sensitive to monitor for
improving glycemic control during intensive insulin treatment of type 1 DM dogs. Blood cells such as leukocytes are much more readily
available than muscle or adipose tissue for studies in dogs.
KEY wORDS: diabetes mellitus, dogs, insulin receptor substrate, intensive glycemic control, leukocytes.

Diabetes mellitus (DM) is a commonly encountered endocrine disease affecting dogs with an ever increasing prevalence. Type $1 \mathrm{DM}$ (>50\% of DM cases) appears to be the most common form of canine diabetes [45], and insulin injections are commonly used as an effective treatment for long-term glycemic control, as is the case with humans [17]. It has been previously demonstrated that intensive insulin treatment can substantially reduce the onset and progression of diabetic complications in human patients suffering from type $1 \mathrm{DM}$ [14]. Although, intensive insulin treatment should be considered and probably recommended for most patients with type $1 \mathrm{DM}$ [13], its implementation is difficult due to the rigorous requirement of constant monitoring of the patient to prevent hypoglycemia. It has been reported that diabetic dogs with inadequate glycemic control have immune system abnormalities [35], especially increased susceptibility to infections [26] and a higher risk for rapid development of cataracts [17]. Interestingly, a prominent feature during immune response is an increase of glucose utilization by white blood cells. As such, it has been suggested that insulin may regulate the immune response either directly [53] or indirectly by influencing the energy balance of the immune cells [24]. Therefore, intensive glycemic control treatment would be important to delay the onset of cataract formation and ameliorate the immune state in these

\footnotetext{
* Correspondence to: Mori, A., School of Veterinary Nursing \& Technology, Faculty of Veterinary Science, Nippon Veterinary and Life Science University, 1-7-1 Kyonancho, Musashino, Tokyo 180-8602, Japan.

e-mail: amori@nvlu.ac.jp
}

animals. Currently, the benefits of intensive glycemic control treatment for type $1 \mathrm{DM}$ dogs have yet to be reported in the literature. In addition, a major risk associated with intensive insulin treatment in diabetic dogs is recurrent hypoglycemia [36].

A major action of insulin is regulation of the metabolic pathways of protein, glycogen and fatty acid synthesis. Insulin binding to the extracellular $\alpha$-subunit of its receptor results in autophosphorylation of tyrosine residues in the receptor $\beta$-subunit and activation of a tyrosine residue intrinsic to the $\beta$-subunit [12]. This leads to recruitment and tyrosine phospohrylation of intracellular substrates such as insulin receptor substrates (IRS) 1-4. Phosphotyrosines on the IRS proteins bind the $\mathrm{p} 85$ regulatory subunit of phosphatidylinositol 3-kinase (PI3-K), which is a heterodimer of a regulatory subunit ( $\mathrm{p} 85)$ and a catalytic subunit (p110). Its activation, in response to insulin, results primarily through its association with the IRS proteins [59]. Subsequently, PI3-K activation is required for GLUT4 translocation and subsequent glucose uptake. In particular, IRS-1, IRS-2 and PI3-K P-85 $\alpha$ are important downstream players of insulin [59] and have been implicated with the incidence of insulin resistance and DM [22, 28, 48]. They are expressed in insulin-sensitive tissues such as the liver, skeletal muscle, abdominal fat and peripheral leukocytes [33, 34].

Insulin exhibits a strong regulatory function in leukocytes $[11,15,23,30,41,47]$ with the major action being, in peripheral leukocytes, regulation of glycolytic enzymes and increased GLUT protein on their plasma membranes [5, 32]. However, the signaling pathway(s) in leukocytes involved 
in mediating the effects of insulin from its receptor and downstream have yet to be fully elucidated. Although resting human peripheral T-lymphocytes are devoid of insulin receptors, these receptors emerge upon activation of cells by specific antigens or mitogens $[23,24]$. Furthermore, it has been shown that neutrophils and monocytes are equipped with insulin receptors $[6,19]$. Although insulin binding with monocytes appears to mirror the receptor status in insulin target tissues such as the liver, muscle and fat [44], it still remains unclear whether monocytes reflect the same changes that occur in insulin receptors at the level of the major insulin target tissues during different pathophysiologic states.

Previously, our laboratory demonstrated that leukocytes can be used to indirectly monitor changes in certain insulinsensitive tissues depending on what marker is utilized [34]. Leukocytes are usually used in clinical studies on insulin action because they are 1) insulin target cells and 2) easy to access as opposed to other insulin-sensitive tissues. Therefore, we sought to determine whether intensive glycemic control treatment for Type $1 \mathrm{DM}$ dogs affects the insulin signaling pathway of peripheral leukocytes. This would thereby provide us with an easy means to gauge and monitor in "real-time" for the efficacy and usefulness of an intensive glycemic control treatment in type $1 \mathrm{DM}$ dogs. As such, the objectives of this study were two-fold. First, concentrations of plasma metabolites and enzyme activities were evaluated to confirm whether intensive glycemic control was achieved in type $1 \mathrm{DM}$ dogs following treatment. Second, quantitative real-time PCR was performed to determine the mRNA expression levels of insulin signaling genes (IRS-1, IRS-2 and PI3-K p85 $\alpha$ ) in the peripheral leukocytes of type $1 \mathrm{DM}$ dogs undergoing intensive insulin treatment. The expression trend was compared against that of peripheral leukocytes, obtained from healthy dogs, cultured with varying insulin concentrations in vitro. We needed to establish whether insulin affects insulin signaling genes and what baseline changes occur in leukocytes from normal healthy dogs since it has never been previously done. In addition, enzyme activities and mRNA levels related to glucose metabolism were also evaluated to investigate whether alterations occur in the peripheral leukocytes of type $1 \mathrm{DM}$ dogs undergoing intensive insulin treatment.

\section{MATERIALS AND METHODS}

Animals: In the present study, nine dogs maintained in our laboratory were split into 2 groups. Three female beagles (7-8 years old) were grouped as healthy dogs. Four beagles ( 3 males and 1 female, 7-9 years old), 1 miniature dachshund (male, 4 years old) and 1 miniature schnauzer (female, 3 years old) were grouped as type $1 \mathrm{DM}$ dogs and glycemic- controlled by insulin injections in our laboratory. All dogs were fed Eukanuba maintenance commercial diet (IAMS, Tokyo, Japan) twice a day ( $8 \mathrm{am}$ and $8 \mathrm{~cm}$ ), and caloric intake was set at $1 / 2 \times 1.8 \times \operatorname{RER}\left(\mathrm{BW}^{0.75} \times 70\right)$ and $1 / 2 \times 2.5 \times \operatorname{RER}\left(\mathrm{BW}^{0.75} \times 70\right)$, where RER means a resting energy requirement and BW means body weight, for the healthy and diabetic dog groups, respectively.

All diabetic dogs had experienced diabetes mellitus for more than three years and were defined as having DM by clinical signs (polyuria and polydipsia) and documentation of persistent fasting hyperglycemia (over $250 \mathrm{mg} / \mathrm{d} l$ ) and glucosuria. The diabetic dogs were treated with insulin combination injections of $0.19-0.53 \mathrm{IU} / \mathrm{kg}$ insulin glargine (Lantus, Sanofi Aventis, Tokyo, Japan) and 0.19-0.84 IU/ $\mathrm{kg}$ human insulin (NPH insulin Novolin N, Novo Nordisk, Tokyo, Japan) twice a day, and their serum glycated albumin (GA) percentages were maintained at 13-20\% (between excellent and good glycemic control) [49] while they were maintained in our laboratory before being used in the current study. Measurement of GA has been advocated in diabetic dogs and can provide an index of glycemic control for the previous 1-3 weeks [49]. All dogs were tested for concurrent diseases by examination of CBC tests and serum biochemistry tests. Approval for this work has been given by the Nippon Veterinary and Life Science University Animal Research Committee.

Plasma metabolite and enzyme analysis: Plasma glucose, total cholesterol, high density lipoprotein (HDL) cholesterol, triglyceride (TG) concentrations, lactate dehydrogenase (LDH), aspartate aminotransferase (AST) and alanine aminotransferase (ALT) activities were determined using an autoanalyzer (AU2700, Olympus Corporation, Tokyo, Japan) with the manufacturer's reagents. The plasma GA level was measured using a commercial kit (Lucica ${ }^{\mathrm{TM}} \mathrm{GA}-$ L, Asahi Kasei Pharma Corp., Tokyo, Japan) described previously [49]. The free fatty acid (FFA) concentration was measured using a commercial kit (NEFA-C test, Wako Pure Chemical Industries, Tokyo, Japan). The plasma adiponectin concentration was measured with a commercial kit (Mouse/Rat Adiponectin ELISA Kit, Otsuka, Tokyo, Japan). Plasma immunoreactive insulin (IRI) concentrations were measured by the ELISA method described previously [35].

Energy metabolism enzyme activity analysis in peripheral leukocytes: The activities of hexokinase (HK) [8], pyruvate kinase (PK) [25], glucose-6-phosphate dehydrogenase (G6PDH) [9], LDH [27], malate dehydrogenase (MDH) [7], glutamate dehydrogenase (GLDH) [50], AST [46], pyruvate carboxylase (PC) [51] and citrate synthase (CS) [29] were measured as previously reported. Enzyme activity was measured at $25 \pm 2{ }^{\circ} \mathrm{C}$ and expressed as $\mathrm{mU}$ per $\mathrm{mg}$ of the amount of protein in the fractions. The enzyme unit (U) was defined as $1 \mu \mathrm{mol}$ of substrate degraded per min. The protein concentration in the fractions was determined by the Bradford assay [10] using bovine serum albumin as a standard.

Total RNA extraction from leukocytes cultured from healthy dogs: Preprandial blood $(10 \mathrm{~m} l)$ was withdrawn from the jugular veins of three healthy dogs into heparinized plastic tubes. The blood samples were immediately centrifuged at $1,700 \mathrm{~g}$ for $10 \mathrm{~min}$ at $4^{\circ} \mathrm{C}$ to obtain peripheral leukocytes isolated from the buffy coat. Excess erythrocytes 
were hemolyzed by lysis solution (Buffer EL, QIAamp RNA Blood Mini, QIAGEN, Tokyo, Japan). The leukocytes were then resuspended in phosphate buffer saline (PBS) and washed twice $\left(1,700 \mathrm{~g}, 10 \mathrm{~min}, 4^{\circ} \mathrm{C}\right)$. The cells $\left(1 \times 10^{6}\right.$ cell $)$ were incubated for $0,1,2$ and $4 \mathrm{hr}$ at $37^{\circ} \mathrm{C}$ in $2 \mathrm{~m} l$ RPMI 1640 (Invitrogen, Tokyo, Japan) containing different concentrations of human insulin (0 (control), 100 and $1000 \mu \mathrm{U} / \mathrm{m} l)$ (Novolin-R, Novo-Nordisk, Tokyo, Japan). After incubation, the leukocytes were resuspended in PBS and washed $\left(1,700 \mathrm{~g}, 10 \mathrm{~min}, 4^{\circ} \mathrm{C}\right)$. Total RNA of peripheral leukocytes was extracted from incubated cells using a commercial kit (QIAamp RNA Blood Mini, QIAGEN, Tokyo, Japan), in accordance with the manufacturer's protocol, and stored at $-80^{\circ} \mathrm{C}$ until further use.

Total RNA extraction from leukocytes from type 1 diabetic dogs undergoing intensive glycemic control treatment: This part of the study was carried out in two phases, and each phase lasted for up to 14 days continuously. In the first phase (Days 1-14), diabetic dogs were injected with different amounts of NPH insulin (average $0.40(0.19-0.66) \mathrm{IU} /$ $\mathrm{kg}$ ) provided as a single injectable administration twice daily. Since the normal recommended dose of NPH for diabetic doses ranges between $0.5-0.7 \mathrm{IU} / \mathrm{kg}$ twice a day [36], the first phase was carried out to worsen glycemic control. In the second phase (Days 15-28), co-administration of insulin glargine (average $0.29(0.19-0.53) \mathrm{IU} / \mathrm{kg}$ ) and $\mathrm{NPH}$ insulin (average $0.5(0.19-0.84) \mathrm{IU} / \mathrm{kg})$ was performed twice daily. The sum total units of NPH and glargine insulin in the second phase were approximately 2-fold greater than units of standalone NPH insulin administered in the first phase of the study. The second phase was carried out to obtain intensive glycemic control. Therefore, the last days (14 days) of the first phase would reflect the worst degree of glycemic control, whereas the last days (28 days) of the second phase should represent the best level glycemic control. Throughout both phases, all dogs were fed a commercial diet (Eukanuba maintenance, IAMS, Tokyo, Japan) twice daily ( 8 am and $8 \mathrm{pm}$ ), and caloric intake was set at $1 / 2 \times 2.5$ $\times$ RER $\left(\mathrm{BW}^{0.75} \times 70\right)$ for each feeding period.

Preprandial blood $(6 \mathrm{~m} l)$ was withdrawn from the jugular veins of the dogs into heparinized plastic tubes on days 14(week 0), 21 (week 1) and 28 (week 2). The blood samples were immediately centrifuged at $1,700 \mathrm{~g}$ for $10 \mathrm{~min}$ at $4^{\circ} \mathrm{C}$ to obtain plasma, which was immediately stored at $-80^{\circ} \mathrm{C}$ until further use. Peripheral leukocytes were isolated from the buffy coat. Cytosolic and mitochondrial fractions were prepared as previously described [57] and stored at $-80^{\circ} \mathrm{C}$ until further use. Total RNA of peripheral leukocytes was extracted from blood samples using a commercial kit (QIAamp RNA Blood Mini, QIAGEN, Tokyo, Japan), in accordance with the manufacturer's protocol, and stored at $-80^{\circ} \mathrm{C}$ until further use.

Quantitative real-time PCR analysis of $m R N A$ : Quantitative real-time (qRT) PCR analysis was performed in order to compare the mRNA levels of peripheral leukocytes. Total RNA samples from peripheral leukocytes were reverse-transcribed into cDNA using a PrimeScript RT Reagent Kit (TaKaRa, Siga, Japan), according to the manufacturer's instructions. The primers used in qRT-PCR, targeting the dog, were designed from the information in GenBank (Table 1). The qRT-PCR reactions for each gene of interest were performed in triplicate with beta-actin serving as an internal standard. The reactions were carried out with a commercial kit (Perfect Real Time SYBR Premix Ex Taq) using an Applied Biosystems 7500 Real Time PCR Sequence Detection System (Applied Biosystems, Foster City, CA, U.S.A.) using the following protocol: $94^{\circ} \mathrm{C}$ for 10 sec, followed by 35 cycles of $95^{\circ} \mathrm{C}$ for $5 \mathrm{sec}$ and $60^{\circ} \mathrm{C}$ for 34 sec. PCR amplification was carried out in $20 \mu l$ reactions containing $2 \mu l$ of template cDNA, $0.4 \mu l$ of each specific primer, $10 \mu l$ of SYBR Premix Ex taq, $0.4 \mu l$ ROX reference dye and $6.8 \mu l$ of distilled water.

Relative gene expression values were calculated by the comparative threshold cycle $(\Delta \Delta \mathrm{Ct})$ method using the Sequence Detection System (SDS) 1.2 software (Applied Biosystems, Foster City, CA, U.S.A.). This method gives the amount of target gene normalized to an endogenous reference gene (beta-actin) and was used to determine the mRNA levels of target genes relative to week 0 or the $0-\mathrm{hr}$ control. Hence, the mRNA level of a target gene was expressed as $n$-fold difference relative to week 0 for the intensive glycemic control study and the $0-\mathrm{hr}$ control for the leukocyte culture study. To determine relative expression levels, the following formula was used: $\Delta \Delta \mathrm{Ct}=\Delta \mathrm{Ct}_{\text {target mRNA }}$

Table 1. Primer sequences for real-time PCR

\begin{tabular}{|c|c|c|c|c|c|}
\hline Probe & $\begin{array}{l}\text { Sequencing length } \\
\text { of PCR products (bp) }\end{array}$ & Primer type & Primer sequences $\left(5^{\prime}-3^{\prime}\right)$ & $\begin{array}{l}\text { GenBank } \\
\text { acc.No. }\end{array}$ & $\begin{array}{c}\text { Human sequence } \\
\text { homology } \%\end{array}$ \\
\hline IRS-1 & 81 & $\begin{array}{l}\text { Forward } \\
\text { Reverse }\end{array}$ & $\begin{array}{l}\text { acctgcgttcaaggaggtctg } \\
\text { cggtagatgccaatcaggttc }\end{array}$ & AB436530 & 97 \\
\hline IRS-2 & 177 & $\begin{array}{l}\text { Forward } \\
\text { Reverse }\end{array}$ & $\begin{array}{l}\text { tggcaggtgaacctgaagc } \\
\text { gaagaagaagctgtccgagtgg }\end{array}$ & AB436531 & 92 \\
\hline PI3-K P85 $\alpha$ & 132 & $\begin{array}{l}\text { Forward } \\
\text { Reverse }\end{array}$ & $\begin{array}{l}\text { gcattaaaccagacctcattcagc } \\
\text { gcgagtattggtcttcagtgttctc }\end{array}$ & AB436617 & 93 \\
\hline G6PDH & 139 & $\begin{array}{l}\text { Forward } \\
\text { Reverse }\end{array}$ & $\begin{array}{l}\text { gctacttcgatgaatttgggatc } \\
\text { cactttaacacttgaccttctcg }\end{array}$ & AB436618 & 97 \\
\hline $\mathrm{MDH}$ & 82 & $\begin{array}{l}\text { Forward } \\
\text { Reverse }\end{array}$ & $\begin{array}{l}\text { ggtgcagccttggagaaatatg } \\
\text { cagtcaggcagttggtattgg }\end{array}$ & AB113364 & 96 \\
\hline beta-actin & 129 & $\begin{array}{l}\text { Forward } \\
\text { Reverse }\end{array}$ & $\begin{array}{l}\text { gccaaccgtgagaagatgact } \\
\text { cccagagtccatgacaataccag }\end{array}$ & AB051104 & 90 \\
\hline
\end{tabular}




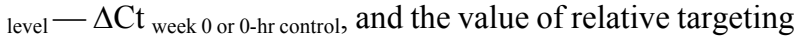
mRNA expression was calculated using the expression $2^{-\Delta \Delta \mathrm{Ct}}$.

Statistical analysis: The qRT-PCR values were expressed as means \pm standard deviation (SD). Plasma metabolite and enzyme values were expressed as means $\pm 95 \%$ confidence intervals (CI). In order to assess significance between groups, Holm-Sidak one-way or two-way repeated-measures post-hoc ANOVA tests were employed whenever appropriate using analysis software (SigmaStat 3.5, Build 3.5.0.54, Systat Software). A difference of $\mathrm{P}<0.05$ was considered statistically significant.

\section{RESULTS}

Plasma metabolite and enzyme analysis for intensive glycemic control in type 1 diabetic dogs: To confirm whether intensive glycemic control was achieved, it was important to monitor key plasma metabolites and enzymes. Mean plasma values of glucose, GA, total and HDL cholesterol, TG, FFA, AST, ALT, LDH, insulin and adiponectin were measured prior to and after intensive insulin treatment (weeks 0, 1 and 2) in the dogs suffering from type $1 \mathrm{DM}$. The results are shown in Table 2. As expected, significant changes $(p<0.05$, Holm-Sidak one-way repeated-measures ANOVA) were observed for the DM group of metabolites and enzymes (glucose, IRI and GA\%) at the end of intensive glycemic control treatment (week 2), thus illustrating improved glycemic control. The plasma glucose levels were reduced by half and were within the $100-150 \mathrm{mg} / \mathrm{d} l$ ideal range, the plasma IRI levels doubled, showing increased insulin concentration, and the mean plasma GA\% decreased to approximately $15 \%$, a value considered to reflect excellent glycemic control [49]. When the lipid metabolism group of metabolites and enzymes (total cholesterol, HDL cholesterol, TG, FFA and adiponectin) was examined, a significant reduction $(\mathrm{p}<0.05$, Holm-Sidak oneway repeated-measures ANOVA) was observed for the total cholesterol and FFA levels at the end of treatment (week 2). In fact, the FFA levels were reduced by approximately $75 \%$. Finally, a series of hepatic injury marker enzymes (AST, ALT and LDH) was examined. No significant changes were observed for AST and ALT, thus indicating that the treatment was not putting additional stress onto the livers of the type 1 DM dogs. Moreover, a significant reduction in LDH $(\mathrm{p}<0.05$, Holm-Sidak one-way repeated-measures ANOVA) was observed, and this could correspond to improved glycemic control after treatment (week 2). Therefore, our overall results indicate that intensive glycemic control was successfully achieved in the type $1 \mathrm{DM}$ dogs.

Quantitative RT-PCR analysis of insulin signaling genes for cultured leukocytes in healthy dogs: To determine whether insulin affects peripheral leukocyte insulin signaling genes, leukocytes isolated and cultured from healthy dogs were incubated for various amounts of time $(0,1,2$ and $4 \mathrm{hr}$ ) and with varying concentrations of insulin ( 0 (control), 100 and $1,000 \mu \mathrm{U} / \mathrm{m} l$ ). Subsequently, qRT-PCR was used to assess changes in insulin gene expression. The results of qRT-PCR are shown in Fig. 1. Insulin treatment under various concentrations and incubation times failed to elicit any significant change in the IRS-1 mRNA expression levels as compared with the non-insulin treated controls. However,

Table 2. Plasma metabolite and enzyme activities in type IDM dogs undergoing intensive glycemic control treatment

\begin{tabular}{|c|c|c|c|c|}
\hline & $\begin{array}{l}\text { Plasma metabolite and } \\
\text { enzyme activities }\end{array}$ & $\begin{array}{c}\text { Week } \\
0\end{array}$ & $\begin{array}{c}\text { Week } \\
1\end{array}$ & $\begin{array}{l}\text { Week } \\
2\end{array}$ \\
\hline \multirow{3}{*}{$\sum$} & Glucose $(\mathrm{mg} / \mathrm{d} l)$ & $382.0 \pm 60.1$ & $212.2 \pm 118.6^{*}$ & $156.7 \pm 72.4^{*}$ \\
\hline & Immunoreactive Insulin $(n \mathrm{~g} / \mathrm{m} l)$ & $21.8 \pm 37.8$ & $35.7 \pm 53.4$ & $48.6 \pm 59.4^{*}$ \\
\hline & Glycated Albumin (\%) & $22.3 \pm 5.2$ & $18.5 \pm 4.4^{*}$ & $15.6 \pm 4.8^{* * * *}$ \\
\hline \multirow{5}{*}{ 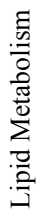 } & Total cholesterol $(\mathrm{mg} / \mathrm{d} l)$ & $306.2 \pm 87.6$ & $261.8 \pm 66.8^{*}$ & $255.0 \pm 71.0^{*}$ \\
\hline & HDL cholesterol $(\mathrm{mg} / \mathrm{d} l)$ & $189.3 \pm 21.4$ & $181.5 \pm 22.2$ & $175.0 \pm 26.4$ \\
\hline & Triglycerides (mg/d $l$ ) & $47.0 \pm 21.2$ & $46.3 \pm 13.2$ & $40.1 \pm 16.3$ \\
\hline & Free faatty acid $(\mathrm{mEq} / l)$ & $1.8 \pm 1.4$ & $1.2 \pm 0.6$ & $0.5 \pm 0.3^{*}$ \\
\hline & Adiponectin $(\mu \mathrm{g} / \mathrm{m} l)$ & $28.8 \pm 16.6$ & $24.3 \pm 12.2$ & $35.0 \pm 25.3$ \\
\hline \multirow{3}{*}{ 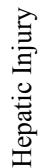 } & Alanine aminotransferase $(\mathrm{U} / l)$ & $94.2 \pm 66.6$ & $98.3 \pm 74.3$ & $68.5 \pm 50.4$ \\
\hline & Aspartate aminotransferase $(\mathrm{U} / l)$ & $50.5 \pm 37.8$ & $36.0 \pm 20.8$ & $32.7 \pm 16.0$ \\
\hline & Lactate dehydrogenase (U/l) & $56.8 \pm 30.9$ & $30.2 \pm 6.0^{*}$ & $27.0 \pm 7.4^{*}$ \\
\hline
\end{tabular}

Values are presented as means $\pm 95 \%$ confidence interval

Single asterisks denote significance ( $<<0.05$, Holm-Sidak one-way repeated-measures post-hoc ANOVA) compared with week 0 .

The double aserisk denote significance ( $\mathrm{p}<0.05$, Holm-Sidak one-way repeated measures post-hoc ANOVA) compared with week 1. 

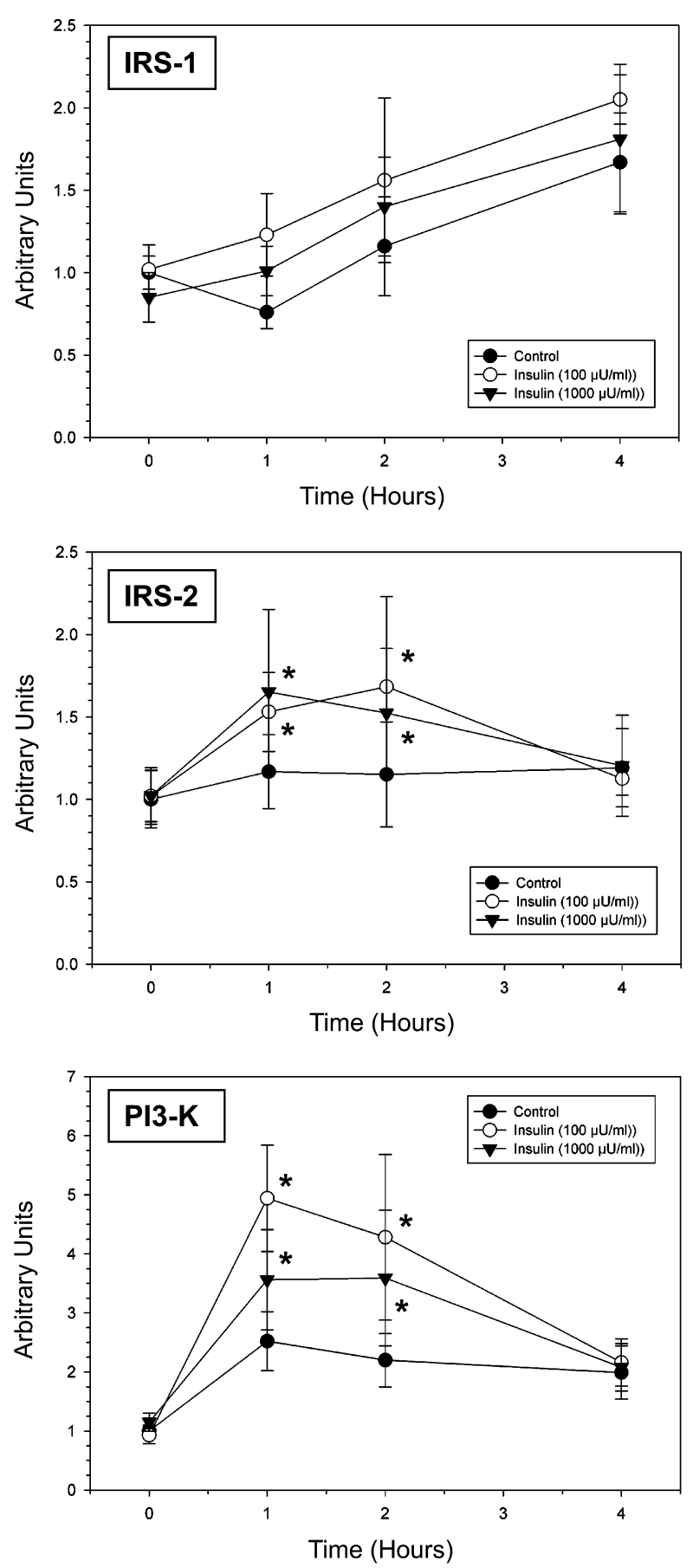

Fig. 1. Determination of changes in insulin signaling gene (IRS1, IRS-2 and PI3-K P85 $\alpha$ ) mRNA expression levels in peripheral leukocytes, obtained from healthy $\operatorname{dogs}(n=3)$ being exposed to insulin, using qRT-PCR. Peripheral leukocytes were incubated with insulin ( 0 (control), 100 and $1,000 \mu \mathrm{U} / \mathrm{m} l)$ and monitored for up to $4 \mathrm{hr}(0,1,2$ and $4 \mathrm{hr})$. Values are the means of three independent experiments \pm standard deviation (SD). The asterisks indicate significance $(\mathrm{p}<0.05$, Holm-Sidak 2-way repeated-measures post-hoc ANOVA test) compared with the control at a similar time point. on the other hand, insulin treatment, regardless of the concentration, provoked a significant increase $(p<0.05$, HolmSidak two-way repeated-measures ANOVA) in IRS-2 mRNA expression ( 0.5 fold more than the control) at $1-2 \mathrm{hr}$ post incubation (Fig. 1, IRS-2 Panel). When PI3-K p85 $\alpha$ mRNA expression was examined, insulin treatment led to a significant increase $(\mathrm{p}<0.05$, Holm-Sidak two-way repeated-measures ANOVA) in expression (2-2.5 fold higher than the control) at $1-2 \mathrm{hr}$ post incubation, mirroring the results observed for IRS-2 expression (Fig. 1, PI3-K panel). It is also interesting to note that for all 3 insulin signaling genes, the higher concentration of insulin $(1000 \mu \mathrm{U} /$ $\mathrm{m} l$ ) tended to result in a slightly decreased level of gene expression as compared with the lower insulin concentration $(100 \mu \mathrm{U} / \mathrm{m} l)$. As such, it appears that high concentrations of insulin may, in fact, downregulate insulin signaling gene expression, acting as a feedback mechanism to prevent hypoglycemia. Therefore, our results for the peripheral leukocytes isolated from the healthy dogs demonstrate that leukocytes do respond to insulin under normal conditions and that changes in insulin signaling genes can be assessed. Moreover, it appears that leukocytes have a preference to use IRS-2 over IRS-1 when activated by insulin.

Quantitative RT-PCR analysis of insulin signaling genes and glucose metabolism enzymes of leuckocytes from Type 1 diabetic dogs undergoing intensive glycemic control treatment: Since insulin signaling genes have been implicated with insulin action, the mRNA levels of IRS-1, IRS-2 and PI3-K P85 $\alpha$ in peripheral leukocytes from type 1 diabetic dogs were examined for changes before and after intensive insulin treatment (weeks 0, 1 and 2). No significant change in expression of IRS-1 was observed. However, IRS-2 expression was 0.75 fold higher at week 1 and was accompanied by a 0.5 fold increase in expression of PI3-K in week 1 (Fig. 2). These results demonstrate a pattern similar to that exhibited by the leukocytes obtained from the normal healthy dogs when treated with insulin. Since differences in insulin gene expression were determined, we wanted to further investigate whether expression of key glucose metabolism enzymes (G6PDH and $\mathrm{MDH}$ ) was also altered after intensive insulin treatment in type $1 \mathrm{DM}$ dogs (Fig. 2). No significant difference in the mRNA expression levels of $\mathrm{MDH}$ or G6PDH were observed after treatment. These results correspond to similar trends observed for the MDH and G6DPH enzyme activities. Overall, our results indicate that intensive glycemic control treatment in type $1 \mathrm{DM}$ dogs results in increased expression of genes in the insulin signaling pathway of peripheral leukocytes. This increased gene expression may be reflective of the animal's improving glycemic control and its improved response to insulin.

Cytosolic and mitochondrial enzyme activities for intensive glycemic control in type 1 diabetic dogs: As a follow-up to our analysis of insulin signaling gene expression, the activity levels of leukocyte cytosolic and mitochondrial enzymes related to glucose metabolism were compared before and after intensive insulin treatment (weeks 0,1 and 2) of type 1 DM dogs. The activities of rate limiting 
IRS-1

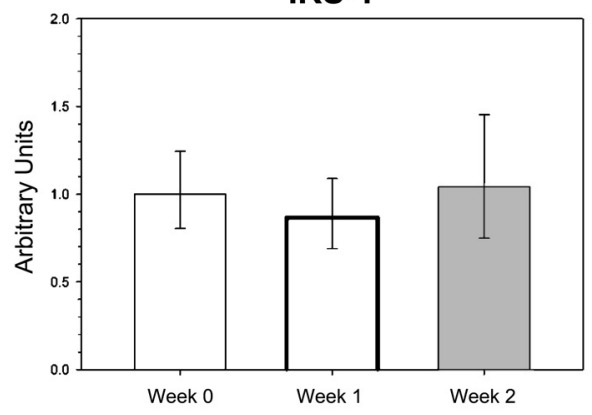

PI3-K

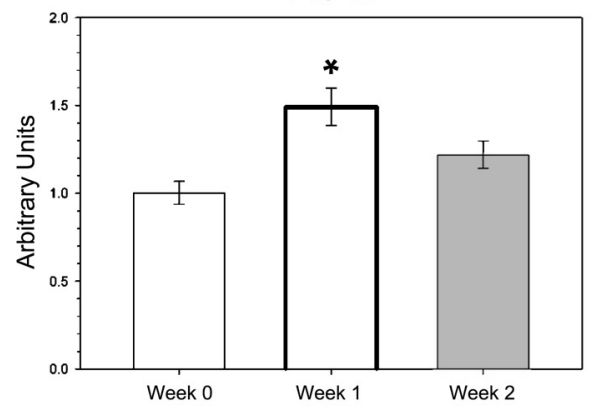

IRS-2

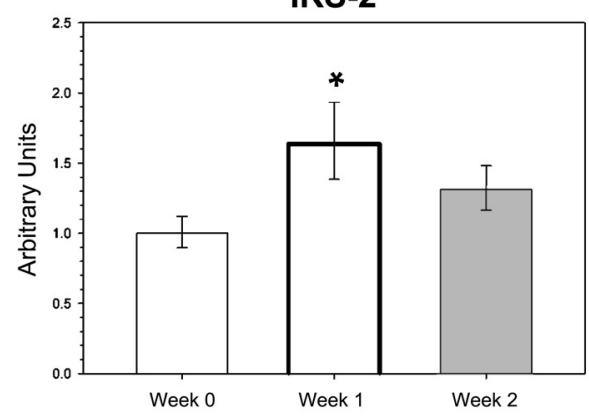

G6DPH

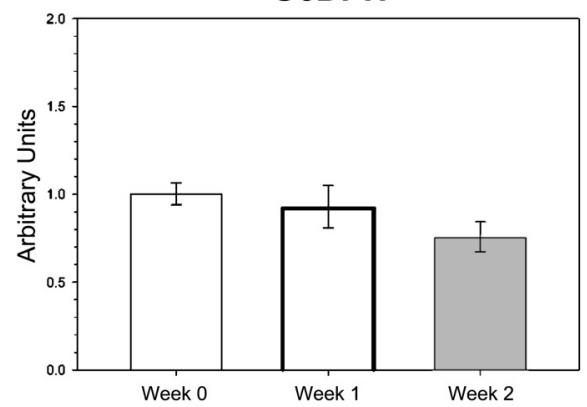

MDH

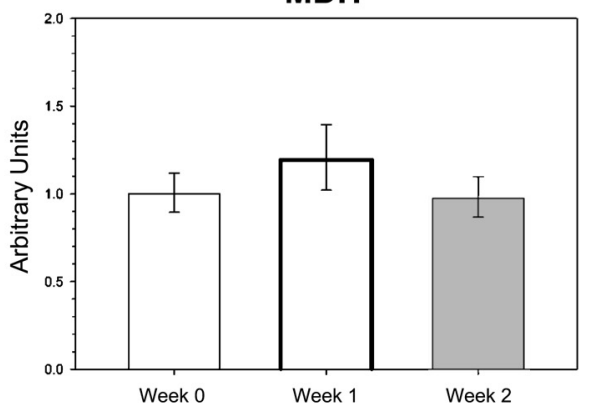

Fig. 2. Determination of changes in insulin signaling gene (IRS-1, IRS-2 and PI3-K P85 $\alpha$ ) and energy metabolism gene (G6DPH and MDH) mRNA expression levels in peripheral leukocytes obtained from type $1 \mathrm{DM}$ dogs $(\mathrm{n}=6)$ before and after intensive insulin treatment (week 0,1 and 2). Values are the means of three independent experiments \pm standard deviation (SD). The asterisks denote significance ( $<<0.05$, Holm-Sidak 2-way repeated-measures post-hoc ANOVA test) compared with control values (week 0).

enzymes of glycolysis (HK and $\mathrm{PK}$ ), pentose phosphate pathway (G6PDH), citric acid cycle (PC and CS), malate aspartate shuttle (MDH and AST), LDH as a cytosolic marker and GLDH as a mitochondrial marker in peripheral leukocytes were measured and are presented in Table 3. No significant differences in the enzyme activities of $\mathrm{HK}$, G6PDH, LDH, MDH, GLDH, AST and CS were observed before and after treatment. However, a significant increase in cytosolic PK and mitochondrial PC was observed. These results suggest that glucose metabolism appears to be more efficient following treatment, and this may be linked to the increase in plasma IRI previously observed. Therefore, these results demonstrate that the type $1 \mathrm{DM}$ dogs, following intensive glycemic control treatment, had increased activities of certain key enzymes involved in glucose metabolism.

\section{DISCUSSION}

After having type $1 \mathrm{DM}$ dogs undergo intensive insulin 
Table 3. Peripheral leukocyte cytosolic and mitochondrial enzyme activities of type I DM dogs undergoing intensive glycemic control treatment

\begin{tabular}{|c|c|c|c|c|}
\hline & Enzyme activities & Week 0 & Week 1 & Week 2 \\
\hline \multirow{6}{*}{$\begin{array}{l}\overline{0} \\
\text { o } \\
\text { 交 }\end{array}$} & $\begin{array}{c}\mathrm{HK} \\
(\mathrm{nmol} / \mathrm{min} / \mathrm{mg})\end{array}$ & $38.3 \pm 11.6$ & $37.2 \pm 5.4$ & $34.0 \pm 8.9$ \\
\hline & $\begin{array}{c}\mathrm{PK} \\
(\mathrm{nmol} / \mathrm{min} / \mathrm{mg})\end{array}$ & $138.2 \pm 48.0$ & $137.5 \pm 51.6$ & $191.2 \pm 39.9^{* * * *}$ \\
\hline & $\begin{array}{c}\text { G6PDH } \\
(\mathrm{nmol} / \mathrm{min} / \mathrm{mg})\end{array}$ & $57.2 \pm 47.4$ & $32.7 \pm 17.4$ & $30.0 \pm 14.8$ \\
\hline & $\begin{array}{c}\text { LDH } \\
(\mathrm{nmol} / \mathrm{min} / \mathrm{mg})\end{array}$ & $2,521.2 \pm 619.7$ & $2,250.0 \pm 354.3$ & $2,129.8 \pm 206.5$ \\
\hline & $\begin{array}{c}\mathrm{MDH} \\
(\mathrm{nmol} / \mathrm{min} / \mathrm{mg})\end{array}$ & $306.7 \pm 60.9$ & $305.3 \pm 50.4$ & $357.3 \pm 85.6$ \\
\hline & $\begin{array}{c}\mathrm{AST} \\
(\mathrm{nmol} / \mathrm{min} / \mathrm{mg})\end{array}$ & $23.2 \pm 7.0$ & $14.7 \pm 2.2$ & $16.5 \pm 3.6$ \\
\hline \multirow{5}{*}{ 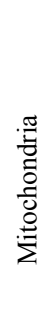 } & $\begin{array}{c}\text { GLDH } \\
(\mathrm{nmol} / \mathrm{min} / \mathrm{mg})\end{array}$ & $437.5 \pm 38.0$ & $438.5 \pm 94.9$ & $501.7 \pm 176.2$ \\
\hline & $\begin{array}{c}\mathrm{MDH} \\
(\mathrm{nmol} / \mathrm{min} / \mathrm{mg})\end{array}$ & $787.5 \pm 72.2$ & $805.8 \pm 176.3$ & $756.7 \pm 233.8$ \\
\hline & $\begin{array}{c}\text { AST } \\
(\mathrm{nmol} / \mathrm{min} / \mathrm{mg})\end{array}$ & $122.3 \pm 25.1$ & $121.0 \pm 40.2$ & $145.5 \pm 57.3$ \\
\hline & $\begin{array}{c}\mathrm{PC} \\
(\mathrm{nmol} / \mathrm{min} / \mathrm{mg})\end{array}$ & $637.7 \pm 198.7$ & $1,052.5 \pm 215.2^{*}$ & $970.7 \pm 243.7 *$ \\
\hline & $\begin{array}{c}\mathrm{CS} \\
(\mathrm{nmol} / \mathrm{min} / \mathrm{mg})\end{array}$ & $96.8 \pm 20.8$ & $81.8 \pm 22.1$ & $84.2 \pm 26.1$ \\
\hline
\end{tabular}

Values are presented as means $\pm 95 \%$ confidence interval.

Single asterisks denote significance $(\mathrm{p}<0.05$, Holm-Sidak one-way repeated-measures post-hoc ANOVA) compared with week 0 .

The double asterisks denote significance $(\mathrm{p}<0.05$, Holm-Sidak one-way repeated measures post-hoc ANOVA) compared with week 1.

treatment, plasma metabolites and enzymes from these animals were examined to confirm whether tight glycemic control was achieved. The enzymes and metabolites were divided into 3 groups: DM, lipid metabolism and hepatic injury. When the DM class of metabolites and enzymes (plasma glucose, GA\% and IRI) was examined, the parameters indicated that intensive glycemic control was achieved. The plasma glucose levels were reduced by half and were within the $100-150 \mathrm{mg} / \mathrm{d} l$ ideal range. In addition, the GA\% decreased to approximately $15 \%$, a value considered to reflect excellent glycemic control [49]. Interestingly, the plasma IRI levels also significantly increased (approximately doubling). Explanation for the increase in IRI is that the IRI analysis method used in our study may cross-react with the insulin preparation used for administration [35]. As such, higher IRI values were observed after undergoing intensive glycemic control treatment.

It has been previously reported that lipid metabolism improves after short-term intensive insulin treatment in human patients suffering from type $2 \mathrm{DM}$ [18]. When the lipid metabolism group of metabolites and enzymes (total cholesterol, HDL cholesterol, TG, FFA and adiponectin) was examined, a significant reduction was observed for the total cholesterol and FFA levels, indicating improved lipid metabolism. In fact, the FFA levels were reduced by approximately $75 \%$, and a reduction in the FFA levels is quite interesting since an elevated level of free fatty acids is believed to cause insulin resistance [18]. This reduction in FFA may indicate improved insulin sensitivity. Lastly, when the hepatic injury group of enzymes (AST, ALT and LDH) was examined, no changes were observed for AST and ALT, thus indicating that intensive insulin treatment was not putting additional stress on the livers of the type 1 DM dogs. However, a significant reduction in LDH was observed after intensive insulin treatment. Individuals suffering from diabetes tend to have elevated plasma LDH levels, and it is believed that overexpression of LDH interferes with normal glucose metabolism and insulin secretion in islet beta-cells $[1,3]$. It may therefore be directly responsible for insulin secretory defects in some forms of type 2 diabetes. Therefore, our overall results from plasma metabolite and enzyme analysis indicate that intensive glycemic control was successfully achieved in the type 1 DM dogs.

Insulin exhibits a strong regulatory function in leukocytes $[11,15,23,30,41,47]$ with the major action being, in peripheral leukocytes, regulation of glycolytic enzymes and increased GLUT protein on their plasma membrane [5, 32]. After having confirmed that our type $1 \mathrm{DM}$ dogs were successfully treated, we wanted to see what effect intensive insulin treatment rendered at the leukocyte level, specifically with regard to insulin signaling activity and energy metabolism. It has previously been reported that under normal conditions, the leukocytes of humans, rats and bovines have high glucose utilization rates $[4,5,21,40,43,60]$. The 
major metabolites from glucose are lactate, pyruvate and $\mathrm{CO}_{2}$ in leukocytes. Furthermore, the ATP required for leukocyte functions is mainly produced by metabolization of glucose to lactate [5]. As the energy production of leukocytes mainly depends on aerobic glycolysis, it is to be expected that ATP production in diabetic cells is depressed. Although leukocytes from human diabetic patients display a decreased rate of glycolysis, these abnormalities are easily corrected with in vivo insulin treatment [2]. Therefore, leukocyte enzymes are considered to be a useful marker to evaluate the energy metabolic condition of animals $[38,55$, 58].

Our working hypothesis was that intensive insulin treatment should increase insulin signaling gene expression in leukocytes from type $1 \mathrm{DM}$ dogs, since insulin would increase cellular metabolism. As such, the mRNA expression levels of IRS-1, IRS-2 and PI3-K P-85 $\alpha$ were focused on since they are important downstream players of the insulin signaling pathway [59]. Interestingly, qRT-PCR revealed no significant change in IRS-1 mRNA expression in peripheral leukocytes from the type $1 \mathrm{DM}$ dogs undergoing treatment. However, a significant increase in IRS-2 (0.6 fold) and PI3-K p $85 \alpha$ ( 0.5 fold) mRNA expression was observed 1 week after treatment. This suggests that changes in insulin signaling were most evident and prevalent during the period of glycemic control improvement (week 1) as compared with the period of glycemic control stabilization (week 2). Moreover, the increase in IRS-2 and PI3-K mRNA expression matches the baseline response to insulin observed for leukocytes isolated from normal healthy dogs when incubated with insulin in vitro. It is known that insulin action on neutrophils is mediated through PI3-kinase activation [42]. Since IRS proteins and PI3-K show a critical link to insulin signaling [52, 54], changes in IRS-1 and/ or IRS-2 expression should be mirrored by changes in PI3$\mathrm{K}$ expression. However, the reason why IRS-1 mRNA expression did not significantly increase could be due to the fact that different IRS proteins predominate in different tissues. This tissue tropism has been observed with rodents [59]. We believe that as a consequence of increased insulin signal pathway activity, glucose transport across the plasma membrane also increased [39]. The glucose transport facilitators are proteins of the GLUT family: GLUT1 and GLUT3 account for basal glucose transport, whilst GLUT 4 is responsible for insulin-stimulated glucose transport [20]. Several studies have shown that GLUT1, GLUT3 and GLUT4 isoforms are expressed in human monocytes, neutrophils and T- and B-lymphocytes [16, 31, 32]. Furthermore, monocytes and B-lymphocytes increase GLUT4 isoform on their plasma membranes in the presence of physiological levels of insulin [32]. Another possible effect of increased insulin signal pathway activity to consider, is that although neutrophils and T-lymphocyte do not require insulin to uptake glucose, glucose metabolism within the cell is insulin dependent [37]. Therefore, the improvement of glucose metabolism within leukocytes and direct immunostimulating effect on the main function of leukocytes could be attributed to insulin action [56]. As such, increased insulin signaling pathway activity appears to have a beneficial effect on leukocyte metabolism.

When assessing the energy metabolism of leukocytes, two energy metabolism genes (MDH and G6DPH) were gauged for changes in mRNA expression following treatment since our working hypothesis also included increased cellular metabolism. MDH is an enzyme in the TCA cycle and is involved in gluconeogenesis. G6PDH is a metabolic cytosolic enzyme involved in the pentose phosphate pathway, which provides NADPH for tissues actively engaged in biosynthesis of fatty acids and/or isoprenoids. No significant differences in the MDH and G6PDH mRNA expression levels of the peripheral leukocytes of the type $1 \mathrm{DM}$ dogs were observed before and after treatment. Moreover, these results correspond to similar trends observed for $\mathrm{MDH}$ and G6DPH at the enzyme level. As such, intensive glycemic control treatment does not manifest any changes in the mRNA expression levels of MDH and G6PDH in peripheral leukocytes. However, we proceeded to examine other leukocyte enzymes involved in energy metabolism. No significant differences in the enzyme activities of $\mathrm{HK}, \mathrm{LDH}$, GLDH and CS were observed in peripheral leukocytes from the type $1 \mathrm{DM}$ dogs after treatment. However, a significant increase in cytosolic PK and mitochondrial PC enzyme activity was observed. Glycolytic enzyme PK is controlled by insulin. As such, the increased enzyme activities of PK may be derived from a higher IRI concentration. Alternatively, PC is essential for gluconeogenesis and serves an anaplerotic role (an enzyme-catalyzed reaction that can replenish the supply of intermediates) for the TCA cycle. Increased PC activity may reflect higher TCA cycle activity. However, the levels of mitochondrial MDH or CS, which is also involved in the TCA cycle, did not increase in this study. No significant change in CS activity has been reported in the neutrophils of diabetic rats, suggesting that the flux of substrates through the TCA cycle is not altered [2]. Furthermore, only $2-3 \%$ of glucose is oxidized through the TCA cycle in neutrophils [5]. Therefore, the relationship between PC and the TCA cycle in peripheral leukocytes should be studied further.

In conclusion, intensive insulin treatment was successful for the type $1 \mathrm{DM}$ dogs in our study. Treatment resulted in a significant decrease in blood glucose and GA\%, leading to improved glycemic control and lipid metabolism in the animals. Moreover, the treatment improved insulin signaling pathway and energy metabolism enzyme activities in peripheral leukocytes, which may have a positive effect on immune status in type $1 \mathrm{DM}$ dogs. Leukocytes are far more accessible and easier to obtain for studies in dogs than muscle or adipose tissue. Therefore, these cells may become a convenient tool for future studies focusing on the influence of diabetes on glucose and insulin metabolism in diabetic dogs. Peripheral leukocytes were successfully used to monitor for changes in insulin signaling and energy metabolism as a result of successful intensive insulin treatment in our study. 
ACKNOWLEDGMENT. This work was supported in part by the 2008 Strategic Research Base Development Program for Private Universities of the Ministry of Education, Culture, Sports, Science and Technology of Japan.

\section{REFERENCES}

1. Ainscow, E.K., Zhao, C. and Rutter, G.A. 2000. Acute overexpression of lactate dehydrogenase-A perturbs $\beta$-cell mitochondrial metabolism and insulin secretion. Diabetes 49: 11491155.

2. Alba-Loureiro, T.C., Hirabara, S.M., Mendonça, J.R., Curi, R. and Pithon-Curi, T.C. 2006. Diabetes causes marked changes in function and metabolism of rat neutrophils. J. Endocrinol. 188: $295-303$.

3. Alcazar, O., Tiedge, M. and Lenzen, S. 2000. Importance of lactate dehydrogenase for the regulation of lgycolytic flux and insulin secretion in insulin-producing cells. Biochem. J. 352: 373-380.

4. Ardawi, M.S. 1988. Glutamine and glucose metabolism in human peripheral lymphocytes. Metabolism 37: 99-103.

5. Beck, W.S. and Valentine, W.N. 1952. The aerobic carbohydrate metabolism of leukocytes in health and leukemia. II. The effect of various substrates and coenzymes on glycolysis and respiration. Cancer. Res. 12: 823-828.

6. Beck-Nielsen, H., Pedersen, O., Kragballe, K. and Sorensen, N.S. 1977. The monocyte as a model for the study of insulin receptors in man. Diabetologia 13: 563-569.

7. Bergmeyer, H.U. and Bernt, E. 1974a. Malate dehydrogenase UV-assay. pp. 613-617. In: Methods of Enzymatic Analysis, vol. 2 (Bergmeyer, H.U. ed.), Verlag Chemie, New York.

8. Bergmeyer, H.U., Gawehn, K. and Grassl, M. 1974b. Hexokinase from yeast. pp. 473-474. In: Methods of Enzymatic Analysis, vol. 1 (Bergmeyer, H.U. ed.), Verlag Chemie, New York.

9. Bergmeyer, H.U., Gawehn, K. and Grassl, M. 1974c. Glucose6-phosphate dehydrogenase from yeast. pp. 458-459. In: Methods of Enzymatic Analysis, vol. 1 (Bergmeyer, H.U. ed.), Verlag Chemie, New York.

10. Bradford, M.M. 1976. A rapid and sensitive method for the quantitation of microgram quantities of protein utilizing the principle of protein-dye binding. Anal. Biochem. 72: 248-254.

11. Cavalot, F., Anfossi, G., Russo, I., Mularoni, E., Massucco, P., Burzacca, S., Mattiello, L. and Trovati, M. 1992. Insulin, at physiological concentrations, enhances the polymorphonuclear leukocyte chemotactic properties. Horm. Metab. Res. 24: 225228.

12. Cheatham, B. and Kahn, C.R. 1995. Insulin action and the insulin signaling network. Endocr. Rev. 16: 117-142.

13. Crofford, O.B. 1995. Diabetes control and complications. Annu. Rev. Med. 46: 267-279.

14. DCTT Research Group. 1993. The effect of intensive treatment of diabetes on the development and progression of long-term complications in insulin-dependent diabetes mellitus. The Diabetes Control and Complications Trial (DCTT) Research Group. N. Engl. J. Med. 329: 977-986.

15. Esmann, V. 1972. The diabetic leukocyte. Enzyme 13: 32-55.

16. Estrada, D.E., Elliott, E., Zinman, B., Poon, I., Liu, Z., Klip, A. and Daneman, D. 1994. Regulation of glucose transport and expression of GLUT3 transporters in human circulating mononuclear cells: studies in cells from insulin-dependent diabetic and nondiabetic individuals. Metabolism 43: 591-598.

17. Feldman, E.C. and Nelson, R.W. 2004. Diabetes mellitus. pp.
486-538. In: Canine and Feline Endocrinology and Reproduction, 3rd., ed. W.B. Saunders, Philadelphia.

18. Fujita, Y., Fukushima, M., Suzuki, H., Taniguchi, A., Nakai, Y., Kuroe, A., Yasuda, K., Hosokawa, M., Yamada, Y., Inagaki, N. and Seino, Y. 2008. Short-term intensive glycemic control improves vibratory sensation in type 2 diabetes. Diabetes Res. Clin. Pract. 80: 16-19.

19. Fussganger, R.D., Kahn, C.R., Roth, J. and De Meyts, P. 1976. Binding and degradation of insulin by human peripheral granulocytes. Demonstration of specific receptors with high affinity. J. Biol. Chem. 251: 2761-2769.

20. Gould, G.W. and Holman, G.D. 1993. The glucose transporter family: structure, function and tissue-specific expression. Biochem. J. 295: 329-341.

21. Guimarães, A.R., Costa-Rosa, L.F., Safi, D.A. and Curi, R. 1993. Effects of a polyunsaturated fatty-acid rich diet on macrophage and lymphocyte metabolism of diabetic rats. Braz. J. Med. Biol. Res. 26: 813-818.

22. Hashimoto, H., Arai, T., Takeguchi, A., Hioki, K., Ohnishi, Y., Kawai, K., Ito, M., Suzuki, R., Yamauchi, T., Ohsugi, M., Saito, M., Ueyama, Y., Tobe, K., Kadowaki, T., Tamaoki, N. and Kosaka, K. 2006. Ontogenetic characteristics of enzyme activities and plasma metabolites in C57BL/6J:Jcl mice deficient in insulin receptor substrate 2. Comp. Med. 56: 176-187.

23. Helderman, J.H. and Strom, T.B. 1977. Emergence of insulin receptors upon alloimmune $\mathrm{T}$ cells in the rat. J. Clin. Invest. 59: 338-344.

24. Helderman, J.H. 1981. Role of insulin in the intermediary metabolism of the activated thymic-derived lymphocyte. $J$. Clin. Invest. 67: 1636-1642.

25. Hess, B. and Wieker, H-J. 1974. Pyruvate kinase from yeast. pp 778-783. In: Methods of Enzymatic Analysis, vol. 2 (Bergmeyer, H.U. ed.), Verlag Chemie, New York.

26. Joshi, N., Caputo, G.M., Weitekamp, M.R. and Karchmer, A.W. 1999. Infections in patients with diabetes mellitus. $N$. Engl. J. Med. 341: 1906-1912.

27. Kaloustian, H.D., Stolzenbach, F.E., Everse, J. and Kaplan, N.O. 1969. Lactate dehydrogenase of lobster (Hornarus americanus) tail muscle. I. Physical and chemical properties. J. Biol. Chem. 244: 2891-2901.

28. Kerouz, N.J., Horsch, D., Pons, S. and Kahn, C.R. 1997. Differential regulation of insulin receptor substrates-1 and -2 (IRS-1 and IRS-2) and phosphatidylinositol 3-kinase isoforms in liver and muscle of the obese diabetic (ob/ob) mouse. $J$. Clin. Invest. 100: 3164-3172.

29. Kosicki, G.W. and Srere, P.A. 1961. Kinetic studies on the citrate-condensing enzyme. J. Biol. Chem. 236: 2560-2565.

30. Kumagai, J., Akiyama, H., Iwashita, S., Iida, H. and Yahara, I. 1981. In vitro regeneration of resting lymphocytes from stimulated lymphocytes and its inhibition by insulin. J. Immunol. 126: $1249-1254$.

31. Longo, N. and Elsas, L.J. 1998. Human glucose transporters. Adv. Pediatr. 45: 293-313.

32. Maratou, E., Dimitriadis, G., Kollias, A., Boutati, E., Lambadiari, V., Mitrou, P. and Raptis, S.A. 2007. Glucose transporter expression on the plasma membrane of resting and activated white blood cells. Eur. J. Clin. Invest. 37: 282-290.

33. Mori, A., Lee, P., Takemitsu, H., Iwasaki, E., Kimura, N., Yagishita, M., Hayasaka, M. and Arai, T. 2009. Decreased gene expression of insulin signaling genes in insulin sensitive tissues of obese cats. Vet. Res. Commun. 33: 315-329.

34. Mori, A., Lee, P., Takemitsu, H., Sako, T. and Arai, T. 2009. Comparison of insulin signaling gene expression in insulin sen- 
sitive tissues between cats and dogs. Vet. Res. Commun. 33: 211-226.

35. Mori, A., Sagara, F., Shimizu, S., Mizutani, H., Sako, T., Hirose, H., Yoshimura, I., Uematsu, Y., Yamaguchi, T. and Arai, T. 2008. Changes in peripheral lymphocyte subsets in the type 1 diabetic dogs treated with insulin injections. J. Vet. Med. Sci. 70: $185-187$.

36. Mori, A., Sako, T., Lee, P., Motoike, T., Iwase, K., Kanaya, Y., Fukuta, H., Mizutani, H. and Arai, T. 2008. Comparison of time-action profiles of insulin Glargine and NPH insulin in normal and diabetic dogs. Vet. Res. Commun. 32: 563-573.

37. Mowat, A. and Baum, J. 1971. Chemotaxis of polymorphonuclear leukocytes from patients with diabetes mellitus. N. Engl. J. Med. 284: 621-627.

38. Muggeo, M., Moghetti, P., Querena, M., Cacciatori, V., Zoppini, G., Zenere, M., Tosi, F., Travia, D. and Bonora, E. 1993. Monnonuclear leukocytes from obese patients with type II diabetes have reduced activity of hexokinase, 6-phosphofructokinase and glucose-6- phosphate dehydrogenase. Horm. Metab. Res. 25: 160-164.

39. Newsholme, E.A. and Dimitriadis, G. 2001. Integration of biochemical and physiologic effects of insulin on glucose metabolism. Exp. Clin. Endocrinol. Diabetes. 109: S122-134.

40. Newsholme, E.A., Newsholme, P. and Curi, R. 1987. The role of the citric acid cycle in cells of the immune system and its importance in sepsis, trauma and burns. Biochem. Soc. Symp. 54: 145-162.

41. Okuno, Y. and Gliemann, J. 1988. Effect of chemotactic factors on hexose transport in polymorphonuclear leucocytes. Biochim. Biophys. Acta. 941: 157-164.

42. Oldenborg, P.A. and Sehlin, J. 1998. Insulin-stimulated chemokinesis in normal human neutrophils is dependent on Dglucose concentration and sensitive to inhibitors of tyrosine kinase and phosphatidylinositol 3-kinase. J. Leukoc. Biol. 63: 203-208.

43. Piatkiewicz, P., Czech, A. and Tatoń, J. 2007. Glucose transport in human peripheral blood lymphocytes influenced by type 2 diabetes mellitus. Arch. Immunol. Ther. Exp. (Warsz). 55: 119-126.

44. Powers, A.C., Solomon, S.S. and Duckworth, W.C. 1980. Insulin Degradation by mononuclear cells. Diabetes 29: 27-32.

45. Rand, J.S., Fleeman, L.M., Farrow, H.A., Appleton, D.J. and Lederer, R. 2004. Canine and feline diabetes mellitus: nature or nurture? J. Nutr. 134: 2072S-2080S.

46. Rej, R. and Horder, M. 1983. Aspartate aminotransferase (glutamate oxaloacetate transaminase). pp. 416-433. In: Methods of Enzymatic Analysis, vol. 3 (Bergmeyer, H.U. ed.), Verlag Chemie, New York.

47. Roep, B.O. 2003. The role of $\mathrm{T}$ cells in the pathogenesis of Type 1 diabetes: from cause to cure. Diabetologia 46: 305321.

48. Rondinone, C.M., Wang, L.M., Lonnroth, P., Wesslau, C.,
Pierce, J.H. and Smith, U. 1997. Insulin receptor substrate (IRS) 1 is reduced and IRS-2 is the main docking protein for phosphatidylinositol 3-kinase in adipocytes from subjects with non-insulin-dependent diabetes mellitus. Proc. Natl. Acad. Sci. U.S.A. 94: 4171-4175.

49. Sako, T., Mori, A., Lee, P., Takahashi, T., Izawa, T., Karasawa, S., Furuuchi, M., Azakami, D., Mizukoshi, M., Mizutani, H., Kiyosawa, Y. and Arai, T. 2008.Diagnostic significance of serum glycated albumin in diabetic dogs. $J$. Vet. Diagn. Invest. 20: 634-638.

50. Schmidt, E. 1974. Glutamate dehydrogenase UV-assay. pp. 650-656. In: Methods of Enzymatic Analysis, vol. 2 (Bergmeyer, H.U. ed.), Verlag Chemie, New York.

51. Scrutton, M.C., Olmsted, M.R. and Utter, M.F. 1969. Pyruvate carboxylase from chicken liver. pp. 235-250. In: Methods of Enzymology, vol. 13 (Lowenstein, J.M. ed.), Academic Press, New York.

52. Shimomura, I., Matsuda, M., Hammer, R.E., Bashmakov, Y., Brown, M.S. and Goldstein, J.L. 2000. Decreased IRS-2 and increased SREBP-1c lead to mixed insulin resistance and sensitivity in livers of lipodystrophic and ob/ob mice. Mol. Cell. 6: 77-86.

53. Strom, T.B., Bear, R.A. and Carpenter, C.B. 1975. Insulininduced augmentation of lymphocyte-mediated cytotoxicity. Science 187: 1206-1208.

54. Sun, Y., Liu, S., Ferguson, S., Wang, L., Klepcyk, P., Yun, J.S. and Friedman, J.E. 2002. Phosphoenolpyruvate carboxykinase overexpression selectively attenuates insulin signaling and hepatic insulin sensitivity in transgenic mice. J. Biol. Chem. 277: 23301-23307.

55. Takeguchi, A., Urabe, S., Tanaka, A., Sako, T., Washizu, T., Morinaga, N., Kimura, N. and Arai, T. 2005. Activities of enzymes in some types of peripheral leucocytes may reflect the differences in nutrient metabolism between dogs and cats. Res. Vet. Sci. 78: 21-24.

56. Walrand, S., Guillet, C., Boirie, Y. and Vasson, M.P. 2004. In vivo evidences that insulin regulates human polymorphonuclear neutrophil functions. J. Leukoc. Biol. 76: 1104-1110.

57. Washizu, T., Kuramoto, E., Abe, M., Sako, T. and Arai, T. 1998. A comparison of the activities of certain enzymes related to energy metabolism in leukocytes in dogs and cats. Vet. Res. Commun. 22: 187-192.

58. Washizu, T., Takahashi, M., Azakami, D., Ikeda, M. and Arai, T. 2001. Activities of enzymes in the malate-aspartate shuttle in the peripheral leukocytes of dogs and cats. Vet. Res. Commun. 25: 623-629.

59. White, M.F. 1998. The IRS signaling system: a network of docking proteins that mediate insulin and cytokine action. Recent. Prog. Horm. Res. 53: 119-138.

60. Wu, G. and Greene, L.W., 1992. Glutamine and glucose metabolism in bovine blood lymphocytes. Comp. Biochem. Physiol. B 103: 821-825. 